\title{
Assessment of nutritional risk in elderly adults of a senior residence - a case study
}

\author{
Avaliação do risco nutricional em idosos utentes de uma residência sénior - um estudo de caso \\ Diana Pereira ${ }^{1}$, Cíntia Ferreira-Pêgo ${ }^{2}$, and Bruno Sousa ${ }^{2 *}$
}

${ }^{1}$ School of Sciences and Health Technologies, Universidade Lusófona de Humanidades e Tecnologias, Av. Campo Grande 376, 1749-024 Lisbon, Portugal; ${ }^{2}$ CBIOS - Universidade Lusófona's Research Center for Biosciences \& Health Technologies, Campo Grande 376, 1749-024 Lisboa, Portugal

*corresponding author / autor para correspondência: bruno.sousa@ulusofona.pt

\begin{abstract}
Elderly adults have reduced appetite and energy expenditure, and possible malnutrition is related to the decline in biological and physiological functions, as well as its consequences. The aim of this study was to assess the nutritional status and malnutrition risk in elderly adults living in a senior residence. A cross-sectional observational analysis was carried out between February and March 2019 in a private senior residence in which the complete Mini Nutritional Assessment (MNA) was applied. It was observed that of the total of 45 participants, 5 individuals had a normal nutritional status, 18 had malnutrition and 22 were at risk. Malnutrition was related to a decrease in intake in the last 3 months $(p=0.015)$ or to the fact that they experienced some type of psychological stress or acute illness in the same period ( $\mathrm{p}=0.023)$. A higher incidence of malnutrition was also found in bedridden individuals or those in wheelchairs $(\mathrm{p}<0.001)$, as well as in patients with severe dementia $(\mathrm{p}=0.010)$, with the presence of skin lesions or bedsores $(\mathrm{p}=0.006)$, weight loss in the previous 3 months $(\mathrm{p}=0.003)$, and decreased fluid consumption $(\mathrm{p}=0.017)$. In conclusion, in this residence we verified that the malnutrition and malnutrition risk values are high, highlighting the need for nutritional intervention.
\end{abstract}

Keywords: Elderly adults, Malnutrition, Nutrition assessment, Nutritional status

\begin{abstract}
Resumo
Os idosos apresentam apetite e gasto energético reduzidos, e a possível desnutrição está relacionada com o declínio nas funções biológicas e fisiológicas, assim como com as suas consequências. O objetivo do presente trabalho consistiu em avaliar o estado nutricional e o risco de desnutrição em idosos institucionalizados numa residência sénior. Foi realizada uma análise observacional transversal, entre fevereiro e março de 2019, numa residência sénior privada, na qual foi aplicado o Mini Nutritional Assessment (MNA) completo. Do total de 45 participantes, 5 indivíduos $(11,1 \%)$ apresentaram um estado nutricional adequado, 18 apresentaram desnutrição (40,0\%) e 22 estavam sob risco (48,9\%). A desnutrição estava relacionada com uma diminuição da ingestão alimentar nos últimos 3 meses $(\mathrm{p}=0,015)$ ou com o facto de terem passado por algum tipo de stress psicológico ou doença aguda no mesmo período de tempo $(\mathrm{p}=0,023)$. Também se encontrou uma maior prevalência de desnutrição em indivíduos acamados ou em cadeiras de rodas $(p<0,001)$, assim como em pacientes com demência grave $(\mathrm{p}=0,010)$, com presença de lesões na pele ou escaras $(\mathrm{p}=0,006)$, perda de peso nos últimos 3 meses ( $p=0,003)$, e consumo $<3$ copos de líquidos/dia $(p=0,017)$. Como conclusão, nesta residência verificamos que os valores de desnutrição e de risco de desnutrição são elevados, evidenciando a necessidade de uma intervenção nutricional.
\end{abstract}

Palavras-chave: Avaliação nutricional, Desnutrição, Estado nutricional, Idosos 


\section{Introduction}

According to the PORDATA website, $21.7 \%$ of the total Portuguese population was 65 years old or older in 2018, an increase over recent years (1). Ageing is a process, conditioned by biological, social, environmental, historical, and cultural factors $(2,3)$. Elderly adults generally have a reduced appetite and energy expenditure, which may be related to the decline in biological and physiological functions, such as reduced lean body mass, and/or changes in the levels of cytokines and hormones, and/or changes in the regulation of electrolytes in body fluids, which have an independent effect on the delay of gastric emptying which may lead to a decrease in smell and taste $(2,3)$. Additionally, pathological and social changes of ageing, such as chronic diseases, psychological illnesses, depression, social isolation, and medication intake, play an important role in the complex etiology of malnutrition in aged adults $(2,4)$.

Malnutrition is defined as "a state in which a deficiency or imbalance of energy, protein, or other macroand micronutrients, causes adverse effects on form, function, and clinical outcome" (2). The etiology is multifactorial, and it is not possible to present only one cause (2). It is in this sense that malnutrition is a fundamental element of the health of the elderly population as it largely affects the ageing process, causing a decline in functional status, impaired muscle function, decreased bone mass, immune dysfunction, anemia, reduced cognitive function, poor wound healing, delayed recovery from surgery, higher rates of hospitalization and consequently higher mortality $(2,3)$.

The prevalence of malnutrition is higher in the elderly population as compared to any other age group, especially in the institutionalized elderly population $(2,5)$. According to the Portuguese elderly nutritional status surveillance system (PEN 3S) study (6), 4.8\% of the elderly residing in nursing homes are malnourished while only $0.6 \%$ of the elderly residing in their homes were in the same clinical situation. In the case of risk of malnutrition, it was found to be $38.7 \%$ in nursing homes while for those residing in their usual homes it was $16.9 \%$. Other international studies have also described that more than $30 \%$ of patients at hospital admission were at nutritional risk (7). These data in Portugal are between $28.5 \%$ and $47.3 \%$ (8). However, the assessment of the nutritional risk of institutionalized elderly individuals specifically in each home, in a recurrent manner and a multidisciplinary team, is of special interest to provide information on the nutritional

\section{Introdução}

De acordo com o site PORDATA, no ano de 2018 a população com 65 anos ou mais, representava $21,7 \%$ do total da população portuguesa, observandose um aumento ao longo dos últimos anos (1). O envelhecimento é um processo, condicionado por diversos fatores, sendo eles, biológicos, sociais, ambientais, históricos e culturais $(2,3)$. As pessoas idosas geralmente têm apetite e gasto energético reduzidos, o que pode estar relacionado com o declínio nas funções biológicas e fisiológicas, como redução da massa magra, e/ou alterações nos níveis de citoquinas e hormonas e/ou alterações na regulação de eletrólitos nos fluidos orgânicos, os quais detêm um efeito independente sobre o atraso do esvaziamento gástrico o que pode levar a uma diminuição do olfato e do paladar $(2,3)$. Adicionalmente, alterações patológicas e sociais do envelhecimento, como doenças crónicas, doenças psicológicas, depressão, isolamento social e toma de medicação, desempenham um importante papel na complexa etiologia da desnutrição no idoso $(2,4)$.

A desnutrição define-se como "um estado no qual uma deficiência ou desequilíbrio de energia, proteína ou outros macro e micronutrientes, causa efeitos adversos na forma, função e resultado clínico" (2). A etiologia é multifatorial, não sendo possível apresentar apenas uma causa (2). É neste sentido, que a malnutrição é um elemento importante e fundamental da saúde da população idosa, já que afeta largamente o processo de envelhecimento, causando declínio no estado funcional, função muscular prejudicada, diminuição da massa óssea, disfunção imunológica, anemia, função cognitiva reduzida, má cicatrização de feridas, atraso na recuperação da cirurgia, maiores taxas de internamento hospitalar e consequentemente maior mortalidade $(2,3)$.

A prevalência de desnutrição é superior na população idosa, em comparação com qualquer outra faixa etária, sobretudo em população idosa institucionalizada $(2,5)$. De acordo com o estudo Portuguese Elderly Nutritional Status Surveillance System (PEN 3S) (6), 4,8\% dos idosos que residem em lares estão desnutridos enquanto que apenas $0,6 \%$ dos idosos que residem nas suas casas se encontravam na mesma situação clínica. No caso de risco de desnutrição verificou-se que nos lares este foi igual $38,7 \%$ enquanto que para aqueles que residem nas suas residências habituais foi de $16,9 \%$. Também outros estudos internacionais descreveram que mais de $30 \%$ dos doentes na admissão hospitalar se encontrava em risco nutricional (7). Estes dados em Portugal situamse entre $28,5 \%$ e $47,3 \%$ (8) Contudo, a avaliação do 
status. This same nutritional risk analysis is extremely relevant to promote the coordination of several areas of action, as for (appropriate) adequacy of human resources, including the presence of a nutritionist, as it promotes better use of resources toward positive effects in the correction and treatment of this condition, and consequently in the longevity and quality of life of the elderly adults.

For all these reasons, the main objective of the present study was to assess the nutritional status and malnutrition risk in elderly people institutionalized in a senior residence in Lisbon, as well as to evaluate the factors related to and influencing this malnutrition. risco nutricional dos idosos institucionalizados em específico em cada lar, de forma recorrente e em equipa multidisciplinar, é de especial interesse para fornecer informação sobre o estado nutricional. Esta mesma análise do risco nutricional é de extrema relevância para a promoção da coordenação de diversas áreas de atuação, como para a correta adequação dos recursos humanos, incluindo a presença de um nutricionista, já que promove uma melhor utilização de recursos, objetivando um efeito positivo na correção e tratamento desta condição, e consequentemente na longevidade e qualidade de vida do idoso.

Por todos estes aspetos, o principal objetivo da presente estudo foi avaliar o estado nutricional e o risco de desnutrição em idosos institucionalizados numa residência sénior em Lisboa, assim como avaliar os fatores relacionados e influenciadores dessa mesma desnutrição.

\section{Materials and Methods}

\section{Design and study population}

This study consists of cross-sectional observational analysis specially designed to assess the nutritional status of institutionalized elderly people within a private senior residence in the district of Lisbon between February and March 2019. The entire resident population, a total of 47 adults, was considered eligible for inclusion, however, two did not authorize their participation. Thus, the study sample consisted of 45 elderly adults (96\% of the resident population), 36 females, and 9 males. This study was conducted following the ethical standards outlined in the 1964 Declaration of Helsinki and its subsequent amendments or comparable ethical standards. The management of the evaluated senior residence approved the conduct of the present study. All participants gave informed consent before the evaluation.

\section{Evaluation of nutritional status}

The complete Mini Nutritional Assessment (MNA) was applied by the nutritionist in the presence of the nurse who accompanies the resident to assist in some answers (9-11). This tool consists of 18 questions and is divided into two parts: Screening and Global Assessment. The MNA was applied to provide a quick and unique assessment of the nutritional status of elderly residents in the senior residence. The questionnaire can be applied to elderly patients in outpatient clinics, hospitals, and nursing homes, and has been translated

\section{Material e Métodos}

\section{Desenho e estudo da população}

O presente estudo consiste numa análise observacional transversal, especialmente desenhado para avaliar o estado nutricional de idosos institucionalizados, utentes de uma residência sénior particular do distrito de Lisboa, entre fevereiro e março de 2019. Como critério de inclusão foi considerado o total de utentes residentes o que perfaz um total de 47 idosos, contudo 2 não autorizaram participar neste estudo, sendo assim a amostra foi constituída por 45 idosos $(96 \%$ dos idosos institucionalizados na residência analisada), 36 do sexo feminino e 9 do sexo masculino. O presente estudo foi realizado de acordo com as normas éticas estabelecidas na Declaração de Helsínquia de 1964 e as suas posteriores emendas ou normas éticas comparáveis. A direção da residência sénior avaliada, aprovou a realização do presente estudo. Todos os participantes deram o seu consentimento informado antes da avaliação.

\section{Avaliação do estado nutricional}

O Mini Nutritional Assessment (MNA) completo foi aplicado pelo nutricionista, na presença da enfermeira que acompanha os utentes, para auxílio em algumas respostas (9-11). Esta ferramenta é constituída por 18 questões e dividido em duas partes: Triagem e Avaliação Global. O MNA foi aplicado com o objetivo de fornecer uma avaliação rápida e única do estado nutricional dos idosos residentes na residência sénior. 
into several languages and validated in various clinical settings around the world (3). It consists of simple anthropometric measurements and short questions that can be completed in about 10 minutes. The sum of the MNA score distinguishes between elderly people with adequate nutritional status (with a score greater than or equal to 24 points), malnourished (with a score less than 17 points), and at risk of malnutrition (for scores between 17 and 23.5 points). Anthropometric measurements were performed according to standard procedures using calibrated equipment $(5,8)$. Weight was measured by trained professionals using an electronic scale and recorded to the nearest decigram $(0.1 \mathrm{~kg})$. Height was measured using a calibrated stadiometer, and the value was recorded to the nearest millimeter $(0.1 \mathrm{~cm})$. Height was also assessed with participants standing with their backs to the stadiometer and with feet and knees together, head positioned so that the gaze remained horizontal, according to the Frankfurt plane. All participants wore light clothing and no shoes during all measurements.

Weight and height data in wheelchair-bound and bedridden elderly people who were unable to stand (12) were obtained using estimated measurements, namely for weight by the arm and leg (twin) circumferences (13), and height by the heel-knee distance (14), using the specific formulas. A fixed length (non-elastic) anthropometric tape with a resolution of $0.1 \mathrm{~cm}$ was used to measure both perimeters and the heel-knee distance.

The Body Mass Index (BMI) was calculated using the normalized formula [Weight (in kg)/Height ${ }^{2}$ (in m)].

\section{Statistical analysis}

Data are presented as means and standard deviation (SD) for continuous variables or numbers (n) and percentages (\%) for categorical variables. The distribution of selected characteristics was compared between groups, gender, or nutritional status categories according to MNA, using Pearson $\chi^{2}$ tests for categorical variables or Student's t-tests or analysis of variance (ANOVA), as appropriate, for continuous variables. All statistical tests were two-tailed, and the significance level was set at $p<0.05$. All analyses were performed using SPSS software version 23.0 (SPSS Inc, Chicago, IL).
O questionário pode ser aplicado em pacientes idosos em ambulatórios, hospitais e casas de repouso, tendo sido traduzido em vários idiomas e validado em vários contextos clínicos em todo o mundo (3). É composto por medições antropométricas simples e perguntas breves que podem ser concluídas em cerca de 10 minutos. A soma do resultado do MNA distingue entre idosos com: estado nutricional adequado (com pontuação superior ou igual a 24 pontos), desnutrido (com pontuação inferior a 17 pontos) e sob risco de desnutrição (se obtiver uma pontuação entre 17 e 23,5 pontos). As medições antropométricas foram efetuadas de acordo com procedimentos padrão, utilizando equipamentos calibrados $(5,8)$. O peso foi medido por profissionais treinados utilizando uma balança eletrónica e registado o valor no decigrama mais próximo $(0,1 \mathrm{~kg})$. A estatura foi medida utilizando um estadiómetro calibrado e o valor foi registrado no milímetro mais próximo $(0,1 \mathrm{~cm})$. A estatura foi avaliada com os participantes de pé, de costas para o estadiómetro e com os pés e joelhos juntos, a cabeça posicionada para que o olhar permanecesse horizontal, de acordo com o plano de Frankfurt. Todos os participantes usaram roupas leves e não usaram sapatos durante todas as medições.

A obtenção de dados de peso e estatura em idosos que se encontravam em cadeiras de rodas e acamados, sendo incapazes de permanecer em pé (12), foi realizada com recurso a medidas estimadas, nomeadamente para o peso através dos perímetros do braço e da perna (geminal) (13), e para a estatura através da distância calcanhar - joelho (14), utilizando as fórmulas específicas. $\mathrm{Na}$ medição de ambos os perímetros e da distância calcanhar - joelho foi utilizada uma fita antropométrica não extensível de resolução de $0,1 \mathrm{~cm}$.

O Índice de Massa Corporal (IMC) foi calculado utilizando a fórmula normalizada [Peso (em $\mathrm{kg}$ )/ Estatura $^{2}$ (em m)].

\section{Análise estatística}

Os dados são apresentados como médias e desvio padrão (DP) para variáveis contínuas ou números (n) e percentagens (\%) para variáveis categóricas. Comparouse a distribuição das características selecionadas entre os grupos, sexos ou categorias de estado nutricional de acordo com o MNA, usando testes de Pearson $\chi^{2}$ para variáveis categóricas ou testes t de Student ou análise de variância (ANOVA), conforme apropriado, para variáveis contínuas. Todos os testes estatísticos foram bicaudais e o nível de significância foi estabelecido em $\mathrm{p}<0,05$. Todas as análises foram realizadas utilizando o software SPSS versão 23.0 (SPSS Inc, Chicago, IL). 
Table 1 - Demographic and nutritional characterization of the total sample and according to gender.

Tabela 1 - Caracterização demográfica e nutricional da amostra total e de acordo com o sexo.

\begin{tabular}{|c|c|c|c|c|}
\hline & $\begin{array}{c}\text { Total population / } \\
\text { População total }(n=45)\end{array}$ & $\begin{array}{l}\text { Women / Mulher } \\
\qquad(\mathrm{n}=36)\end{array}$ & $\begin{array}{l}\text { Men / Homem } \\
\quad(n=9)\end{array}$ & p-value* \\
\hline Age / Idade, years / anos & $84.42(9.06)$ & $85.58(8.27)$ & $79.78(11.03)$ & 0.086 \\
\hline Weight / Peso, kg & $56.66(12.19)$ & $56.13(12.92)$ & $59.87(6.37)$ & 0.579 \\
\hline $\begin{array}{l}\text { Height / Estatura, m } \\
\text { Arm perimeter / }\end{array}$ & $1.51(0.08)$ & $1.48(0.06)$ & $1.63(0.02)$ & $<0.001$ \\
\hline \multicolumn{5}{|l|}{ Perímetro do braço, cm } \\
\hline$<21$ & $15.60(7)$ & $13.90(5)$ & $22.20(2)$ & \multirow{3}{*}{0.661} \\
\hline $21-22$ & $4.40(2)$ & $5.60(2)$ & $0.00(0)$ & \\
\hline$>22$ & $80.00(36)$ & $80.60(29)$ & $77.80(7)$ & \\
\hline \multicolumn{5}{|l|}{ Leg perimeter/ } \\
\hline \multicolumn{5}{|l|}{ Perímetro da perna, cm } \\
\hline$<31$ & $37.80(17)$ & $41.70(15)$ & $22.20(2)$ & \multirow{2}{*}{0.282} \\
\hline$\geq 31$ & $62.20(28)$ & $58.30(21)$ & $77.80(7)$ & \\
\hline BMI / IMC, $\mathbf{k g} / \mathbf{m}^{2}$ & $25.46(5.82)$ & $25.96(6.09)$ & $22.59(2.98)$ & 0.295 \\
\hline \multicolumn{5}{|l|}{ BMI categories / } \\
\hline \multicolumn{5}{|l|}{ Categorias de IMC, \% (n) } \\
\hline$<19$ & $7.7(2)$ & $9.1(2)$ & $0.0(0)$ & \multirow{4}{*}{0.037} \\
\hline $19-21$ & $11.5(3)$ & $4.5(1)$ & $50.0(2)$ & \\
\hline $21-23$ & $11.5(3)$ & $9.1(2)$ & $25.0(1)$ & \\
\hline$\geq 23$ & $69.2(18)$ & $77.3(17)$ & $25.0(1)$ & \\
\hline
\end{tabular}

Data expressed as mean (SD) or percentage (n), as appropriate. ${ }^{*}$ p-value for comparisons between groups (male/female) assessed by Student's t-test for continuous variables or Pearson $\chi^{2}$ for categorical variables. Abbreviations: BMI, Body Mass Index / Dados expressos em média (DP) ou percentagem (n), como apropriado. *Valor P para comparações entre grupos (homem/mulher) avaliado por Teste t de Student para variáveis contínuas ou Pearson $\chi^{2}$ para variáveis categóricas. Abreviaturas: IMC, Índice de Massa Corporal

\section{Results}

Forty-five participants (36 women and 9 men) with a mean age of 84 years (SD: 9 years) participated in the present analysis. The demographic and nutritional characteristics of the population (total and by gender) are shown in Table 1.

No statistically significant differences were found for age, weight, arm circumference, leg circumference, and BMI. However, men are significantly taller than women and a lower proportion of men were found in the BMI categories $<19 \mathrm{~kg} / \mathrm{m}^{2}$ and $>23 \mathrm{~kg} / \mathrm{m}^{2}$.

Table 2 shows the assessment of indicator characteristics of nutritional status based on the MNA for the total sample and according to the gender of the participants. No significant differences were observed in any of the parameters previously analyzed. Also, no statistical differences were observed regarding the final MNA score or its categories in the distribution by gender.

\section{Resultados}

Participaram na presente análise 45 participantes (36 mulheres e 9 homens), com uma idade média de 84 anos (DP: 9 anos).

As características demográficas e nutricionais da população, para a amostra total e de acordo com o sexo podem ser observadas na Tabela 1. Não foram encontradas diferenças estatisticamente significativas para a idade, peso, perímetro do braço, perímetro da perna e IMC. Contudo, os homens são significativamente mais altos do que as mulheres e encontrou-se uma menor proporção de homens nas categorias de IMC $<19 \mathrm{~kg} / \mathrm{m}^{2}$ e $\geq 23 \mathrm{~kg} / \mathrm{m}^{2}$.

A Tabela 2 mostra a avaliação de características indicadoras do estado nutricional com base no MNA para a amostra total e de acordo com o sexo dos participantes. Não foram observadas diferenças significativas em nenhum dos parâmetros anteriormente analisados. Também não foram observadas diferenças estatísticas no que toca à pontuação final do MNA ou suas categorias na distribuição por sexo. 
Finally, nutritional status was assessed based on the three categories of the final MNA score (Table 3). Of the total sample, 5 participants had an adequate nutritional status, 18 had malnutrition, and 22 were at risk. There were no relationships between nutritional status and gender, age, or BMI. However, there were significant differences in the variables "decreased food intake in the past three months," "weight loss in the past three months," "mobility," "experiencing psychological stress or acute illness in the past three months," "neuropsychological problems," "presence of skin lesions or bedsores," and "fluid intake." The largest percentage of malnourished participants had a moderate to severe decrease in intake in the three months prior the interview, as well as greater weight loss during the same period. Concerning mobility, there is a higher percentage of bedridden or wheelchair-bound individuals presenting malnutrition: $88.90 \%$ of the bedridden or wheelchair-bound individuals and $11.10 \%$ of ambulatory individuals presented malnutrition. Of the institutionalized users with malnutrition, $66.70 \%$ had experienced some type of psychological stress or acute illness in the three months prior to completing the questionnaire. It is also noteworthy that the majority of patients with severe dementia presented malnutrition, as did all the participants with the presence of skin lesions or bedsores. Finally, half of the elderly users with malnutrition consumed less than three cups of liquid per day.

\section{Discussion}

Nutritional risk assessment through the MNA may contribute to the early diagnosis of nutritional status and prevention of a possible deterioration of the general health status. In the present study, the MNA was applied to elderly adults institutionalized in a senior residence in the district of Lisbon, and we found that $40.0 \%$ were malnourished and $48.9 \%$ were at risk of malnutrition. The high prevalence of the elderly at nutritional risk has been recently observed both nationally and worldwide (15).

The residential situation of elderly adults also determines their nutritional status, their quality of life, and even their physical and psychological wellbeing (16). In a systematic review and meta-analysis of data on nutritional status in older persons using the MNA, the prevalence of malnutrition was differentiated
Por último, foi avaliado o estado nutricional com base nas 3 categorias da pontuação final no MNA (Tabela 3). Do total da amostra, 5 participantes apresentaram um estado nutricional adequado, 18 apresentaram desnutrição e 22 estavam sob risco. Não existiram relações entre o estado nutricional e o sexo, idade ou IMC. Contudo, existiram diferenças significativas nas variáveis "diminuição da ingestão alimentar nos últimos 3 meses", "perda de peso nos últimos 3 meses", "mobilidade", "passar por situações de stress psicológico ou doença aguda nos últimos 3 meses", "problemas neuropsicológicos", "presença de lesões na pele ou escaras", e "consumo de líquidos". A maior percentagem de participantes desnutridos apresentava uma diminuição moderada a grave de ingestão nos últimos 3 meses anteriores à entrevista, assim como maior perda de peso durante o mesmo período de tempo. Em relação à mobilidade, existe maior percentagem de indivíduos acamados ou em cadeiras de rodas que apresentam desnutrição: $88,9 \%$ dos indivíduos acamados ou em cadeiras de rodas, assim como 11,1\% dos que deambulavam apresentaram desnutrição. Dos utentes institucionalizados com desnutrição, 66,7\% passaram por algum tipo de stress psicológico ou doença aguda no período que correspondia aos 3 meses antecedentes ao preenchimento do questionário. É também de salientar que a maioria dos pacientes com demência grave, apresentaram desnutrição, assim como a totalidade dos participantes com presença de lesões na pele ou escaras. Finalmente, a metade dos utentes idosos com presença de desnutrição consumiram menos de três copos de líquidos por dia.

\section{Discussão}

A avaliação do risco nutricional através do MNA poderá contribuir para o diagnóstico precoce do estado nutricional e prevenção de uma possível deterioração do estado geral de saúde. No presente estudo foi aplicado o MNA em idosos institucionalizados numa residência sénior do distrito de Lisboa, e verificamos que $40,0 \%$ apresentavam desnutrição e 48,9\% estavam sob risco de desnutrição. A elevada prevalência de idosos em risco nutricional é algo que tem vindo a ser observado ultimamente, tanto a nível nacional como mundial (15).

O local onde os idosos habitam também determina o seu estado nutricional, a qualidade de vida e mesmo o seu bem-estar físico e psicológico (16). Numa revisão sistemática e meta-análise de dados sobre o estado nutricional em pessoas idosas usando o MNA, a prevalência de desnutrição diferiu significativamente 
Table 2. Evaluation of nutritional status indicator characteristics based on MNA for the total sample and according to gender.

Tabela 2. Avaliação de características indicadoras do estado nutricional com base no MNA para a amostra total e de acordo com o sexo.

\begin{tabular}{|c|c|c|c|c|}
\hline & $\begin{array}{l}\text { Total sample / } \\
\text { Amostra total } \\
\quad(n=45)\end{array}$ & $\begin{array}{c}\text { Women / } \\
\text { Mulher } \\
(\mathbf{n}=36)\end{array}$ & $\begin{array}{l}\text { Men / Homem } \\
\quad(\mathbf{n}=9)\end{array}$ & p-value* \\
\hline $\mathbf{M N A}^{\#}$ & $18.07(5.11)$ & $18.22(4.97)$ & $17.44(5.87)$ & 0.688 \\
\hline $\begin{array}{l}\text { MNA categories / categorias, } \% \text { (n) } \\
\text { Normal nutritional status / Estado nutricional normal } \\
\text { At risk of malnutrition / Sob risco de desnutrição } \\
\text { Malnourished / Desnutrido }\end{array}$ & $\begin{array}{l}11.1(5) \\
48.9(22) \\
40.0(18)\end{array}$ & $\begin{array}{l}11.1(4) \\
52.8(19) \\
36.1(13)\end{array}$ & $\begin{array}{l}11.1(1) \\
33.3(3) \\
55.6(5)\end{array}$ & 0.539 \\
\hline \multicolumn{5}{|l|}{$\begin{array}{l}\text { Decreased food intake last } 3 \text { months / } \\
\text { Diminuição de ingestão alimentar últimos } 3 \text { meses }\end{array}$} \\
\hline $\begin{array}{l}\text { Severe / Severa } \\
\text { Moderate / Moderada } \\
\text { No decrease / Sem diminuição }\end{array}$ & $\begin{array}{l}4.4(2) \\
40.0(18) \\
55.6(25)\end{array}$ & $\begin{array}{l}2.8(1) \\
44.4(16) \\
52.8(19)\end{array}$ & $\begin{array}{l}11.1(1) \\
22.2(2) \\
66.7(6)\end{array}$ & 0.322 \\
\hline \multicolumn{5}{|l|}{$\begin{array}{l}\text { Weight loss in the last } 3 \text { months / } \\
\text { Perda de peso nos últimos } 3 \text { meses, } \mathrm{kg}\end{array}$} \\
\hline $\begin{array}{l}\text { No loss / Sem perda } \\
1-3 \\
>3\end{array}$ & $\begin{array}{l}55.6(25) \\
37.8(17) \\
6.7(3)\end{array}$ & $\begin{array}{l}52.8(19) \\
38.9(14) \\
8.3(3)\end{array}$ & $\begin{array}{c}66.7(6) \\
33.3(3) \\
0.0(0)\end{array}$ & 0.589 \\
\hline $\begin{array}{l}\text { Mobility / Mobilidade } \\
\text { Bedridden or wheelchair-bound / }\end{array}$ & $53.3(24)$ & $55.6(20)$ & $44.4(4)$ & \multirow[b]{2}{*}{0.694} \\
\hline $\begin{array}{l}\text { Walks / Deambula } \\
\text { Normal }\end{array}$ & $\begin{array}{l}44.4(20) \\
2.2(1)\end{array}$ & $\begin{array}{l}41.7(15) \\
2.8(1)\end{array}$ & $\begin{array}{l}55.6(5) \\
0.0(0)\end{array}$ & \\
\hline $\begin{array}{l}\text { Psychological stress or acute illness last } 3 \text { months / } \\
\text { Stress psicológico ou doença aguda últimos } 3 \text { meses }\end{array}$ & $46.7(21)$ & $50.0(18)$ & $33.3(3)$ & 0.37 \\
\hline \multicolumn{5}{|l|}{$\begin{array}{l}\text { Neuropsychological problems / } \\
\text { Problemas neuropsicológicos }\end{array}$} \\
\hline $\begin{array}{l}\text { Severe dementia / Demência grave } \\
\text { Mild dementia / Demência leve } \\
\text { No problems / Sem problemas }\end{array}$ & $\begin{array}{c}40.0(18) \\
53.3(24) \\
6.7(3)\end{array}$ & $\begin{array}{c}33.3(12) \\
58.3(21) \\
8.3(3)\end{array}$ & $\begin{array}{c}66.7(6) \\
33.3(3) \\
0.0(0)\end{array}$ & 0.166 \\
\hline $\begin{array}{l}\text { Presence of skin lesions or bedsores / } \\
\text { Presença de lesões na pele ou escaras }\end{array}$ & $13.3(6)$ & $11.1(4)$ & $22.2(2)$ & 0.38 \\
\hline \multicolumn{5}{|l|}{$\begin{array}{l}\text { Daily cups of liquid consumed / } \\
\text { Copos diários de líquidos consumidos }\end{array}$} \\
\hline $\begin{array}{l}<3 \\
3-5 \\
>5\end{array}$ & $\begin{array}{l}31.1(14) \\
26.7(12) \\
42.2(19)\end{array}$ & $\begin{array}{l}25.0(9) \\
30.6(11) \\
44.4(16)\end{array}$ & $\begin{array}{l}55.6(5) \\
11.1(1) \\
33.3(3)\end{array}$ & 0.183 \\
\hline \multicolumn{5}{|l|}{$\begin{array}{l}\text { Number of meals daily / } \\
\text { Número de refeições diárias }\end{array}$} \\
\hline $\begin{array}{l}1 \\
2 \\
3\end{array}$ & $\begin{array}{c}2.2(1) \\
2.2(1) \\
95.6(45)\end{array}$ & $\begin{array}{c}2.8(1) \\
2.8(1) \\
94.4(34)\end{array}$ & $\begin{array}{c}0.0(0) \\
0.0(0) \\
100.0(9)\end{array}$ & 0.77 \\
\hline \multicolumn{5}{|l|}{ Intake of / Consumo de: } \\
\hline $\begin{array}{l}1 \text { daily portion of milk or dairy products / } \\
1 \text { porção diária de leite ou derivados }\end{array}$ & $88.9(40)$ & $91.7(33)$ & $77.8(7)$ & 0.236 \\
\hline $\begin{array}{l}2 \text { daily servings of fruit or vegetables / } \\
2 \text { porções diárias de fruta ou hortícolas }\end{array}$ & $97.8(44)$ & $97.2(35)$ & $100.0(9)$ & 0.613 \\
\hline $\begin{array}{l}\text { Meat, fish or poultry every day / } \\
\text { Carne, peixe ou aves todos os dias }\end{array}$ & $93.3(42)$ & $91.7(33)$ & $100.0(9)$ & 0.37 \\
\hline $\begin{array}{l}2 \text { weekly servings of legumes and eggs / } \\
2 \text { porções semanais de leguminosas e ovos }\end{array}$ & $91.1(41)$ & $88.9(32)$ & $100.0(9)$ & 0.295 \\
\hline
\end{tabular}

Data expressed as percentage (n). *p value for comparisons between groups (male/female) evaluated by Pearson $\chi^{2}$. Abbreviations: MNA, Mini Nutritional Assessment. \#MNA: final score from 0 to 30 points./ Dados expressos em percentagem (n). *Valor P para comparações entre grupos (homem/mulher) avaliado por Pearson $\chi^{2}$. Abreviaturas: MNA, Mini Nutritional Assessment. ${ }^{*}$ MNA: pontuação final de 0 a 30 pontos. 
between the healthcare settings: $3.1 \%$ in the community, $6.0 \%$ in the outpatient clinic, $8.7 \%$ in home care services, $22.0 \%$ in the hospital level, $17.5 \%$ in nursing homes, $28.7 \%$ in long-term care units, and $29.4 \%$ in rehabilitation units (17). In Portugal, the prevalence of malnutrition .in the elderly community in general is low, although a high number of elderly are at nutritional risk, compared to institutionalized elderly who are generally malnourished (16). According to the PEN 3S study, $4.8 \%$ of the elderly residing in nursing homes are malnourished while only $0.6 \%$ of the elderly residing in their homes were found with this clinical condition. In nursing homes, the risk of malnutrition was $38.70 \%$, while the risk was $16.90 \%$ for those residing in their own homes (6). A similar situation has been found in Brazil, where the majority of the population is at risk of malnutrition, particularly the institutionalized elderly (18). Differing from the conclusions of this study and other scientific evidence, Saka et al., Serrano-Urrea and García-Meseguer showed that in Turkey and Spain, respectively, the elderly living in institutions were better nourished than in their usual homes $(19,20)$.

The high levels of malnutrition and risk of malnutrition found in our studied senior residence, higher than the data found in the literature, may also be related to its lack of a specialized nutritional technician to carry out these assessments routinely and support any consequent nutritional intervention to avoid these high levels, with clear consequences for the health of these elderly people.

During the ageing process, there is a decrease in both balance and functional mobility, and immobility is one of the factors associated with decreased oral intake $(20,21)$. Our results can be partially explained by this statement, as we observed that only the elderly with adequate nutritional status had normal mobility. In addition, the presence of psychological stress was observed only in the elderly at risk of malnutrition and in the malnourished elderly. It is known that a high incidence of neuropsychological problems can interfere with autonomy and social or professional performance in elderly individuals (22). In this study, malnutrition was associated with severe dementia, a situation also reported in other studies $(23,24)$. On the other hand, the presence of skin lesions or bedsores was only observed in the malnourished elderly. Previously published studies have likewise indicated the existence of associations between malnutrition and the development of pressure ulcers and consequently the difficulty of their healing (21). entre os ambientes de saúde considerados: na comunidade foi de 3,1\%; em ambulatorio de $6,0 \%$; em serviços de atendimento domiciliar de 8,7\%; a nível hospitalar de 22,0\%; lares de idosos de $17,5 \%$; em unidades de cuidados de longo prazo foi de 28,7\%; e em unidades de reabilitação de 29,4\% (17). Em Portugal verifica-se uma baixa prevalência da desnutrição dos idosos na comunidade de forma geral e um elevado número de idosos em risco nutricional, quando comparado com idosos institucionalizados que se encontram maioritariamente desnutridos (16). De acordo com o estudo PEN 3S, 4,8\% dos idosos que residem em lares estão desnutridos enquanto que apenas $0,6 \%$ dos idosos que residem nas suas casas se encontravam na mesma situação clínica. No caso de risco de desnutrição verificou-se que nos lares este risco foi de $38,7 \%$ enquanto que para aqueles que residem nas suas residências habituais foi de $16,9 \%$ (6). O mesmo também se verifica fora de Portugal, nomeadamente no Brasil, onde a maioria da população se encontra em risco de desnutrição, particularmente os idosos institucionalizados à semelhança de Portugal (18). Divergindo das conclusões do presente estudo, assim como de diversa evidência científica, Saka et al., Serrano-Urrea e García-Meseguer demonstraram que na Turquia e em Espanha, respetivamente, os idosos residentes em instituições encontravam-se melhor nutridos do que nas suas residências habituais $(19,20)$.

Os elevados níveis de desnutrição e risco de desnutrição encontrados nesta residência sénior, superiores aos dados encontrados na literatura, também podem estar relacionados com a inexistência na instituição de um técnico especializado na área da nutrição, para realizar estas avaliações por rotina e a consequente intervenção nutricional, para evitar estes níveis elevados, com claras consequências para a saúde destes idosos.

Durante o processo de envelhecimento ocorre uma diminuição tanto do equilíbrio como da mobilidade funcional, já para não referir que a imobilidade é um dos fatores associados à diminuição da ingestão oral $(20,21)$. Os nossos resultados podem em parte ser explicados por esta afirmação, já que observamos que apenas os idosos com estado nutricional adequado apresentavam mobilidade normal. Também a presença de stress psicológico observou-se apenas em idosos sob o risco de desnutrição e em idosos desnutridos. É conhecido que os problemas neuropsicológicos têm alta incidência no idoso interferindo na sua autonomia, no desempenho social ou profissional do indivíduo (22). Neste estudo, a desnutrição esteve associada à demência grave, situação que é igualmente reportada 
Table 3. Evaluation of factors related to nutritional status, according to the categories of nutritional status obtained through the MNA.

Tabela 3. Avaliação dos fatores relacionados com o estado nutricional, de acordo com as categorias de estado nutricional obtidas através do MNA.

\begin{tabular}{|c|c|c|c|c|}
\hline & $\begin{array}{c}\text { Normal nutritional } \\
\text { status / } \\
\text { Estado nutricional } \\
\text { normal } \\
(n=5)\end{array}$ & $\begin{array}{c}\text { At risk of } \\
\text { malnutrition / } \\
\text { Sob risco de } \\
\text { desnutrição } \\
(n=22)\end{array}$ & $\begin{array}{l}\text { Malnourished / } \\
\text { Desnutrido } \\
(\mathbf{n}=18)\end{array}$ & p-value ${ }^{*}$ \\
\hline \multicolumn{5}{|l|}{ Gender/Sexo } \\
\hline Women / Mulher & $11.1(4)$ & $52.8(19)$ & $36.1(13)$ & \multirow{2}{*}{0.539} \\
\hline Men / Homem & $11.1(1)$ & $33.3(3)$ & $55.6(5)$ & \\
\hline \multicolumn{5}{|l|}{ Age / Idade, years / anos } \\
\hline$<85$ & $14.3(3)$ & $42.9(9)$ & $42.9(9)$ & \multirow{2}{*}{0.694} \\
\hline$\geq 85$ & $8.3(2)$ & $54.2(13)$ & $37.5(9)$ & \\
\hline \multicolumn{5}{|l|}{ BMI / IMC, $\mathrm{kg} / \mathbf{m}^{2}$} \\
\hline$<19$ & $0.0(0)$ & $12.5(2)$ & $0.0(0)$ & \multirow{4}{*}{0.177} \\
\hline $19-21$ & $20.0(1)$ & $0.0(0)$ & $40.0(2)$ & \\
\hline $21-23$ & $0.0(0)$ & $18.8(3)$ & $0.0(0)$ & \\
\hline$\geq 23$ & $80.0(4)$ & $68.8(11)$ & $60.0(3)$ & \\
\hline \multicolumn{5}{|l|}{ Decreased food intake last 3 months / } \\
\hline \multicolumn{5}{|l|}{ Diminuição de ingestão alimentar últimos 3 meses } \\
\hline Severe / Severa & $0.0(0)$ & $0.0(0)$ & $11.1(2)$ & \multirow{3}{*}{0.015} \\
\hline Moderate / Moderada & $0.0(0)$ & $31.8(7)$ & $61.1(11)$ & \\
\hline No decrease / Sem diminuição & $100.0(5)$ & $68.2(15)$ & $27.8(5)$ & \\
\hline \multicolumn{5}{|l|}{ Weight loss in the last 3 months / } \\
\hline \multicolumn{5}{|l|}{ Perda de peso nos últimos 3 meses, $\mathrm{kg}$} \\
\hline No loss / Sem perda & $0.0(0)$ & $0.0(0)$ & $16.7(3)$ & \multirow{3}{*}{0.003} \\
\hline $1-3$ & $0.0(0)$ & $27.3(6)$ & $61.1(11)$ & \\
\hline$>3$ & $100.0(5)$ & $72.7(16)$ & $22.2(4)$ & \\
\hline \multicolumn{5}{|l|}{ Mobility / Mobilidade } \\
\hline $\begin{array}{l}\text { Bedridden or wheelchair-bound/ } \\
\text { Acamado ou cadeira de rodas }\end{array}$ & $0.0(0)$ & $36.4(8)$ & $88.9(16)$ & \multirow{3}{*}{$<0.001$} \\
\hline Walks / Deambula & $80.0(4)$ & $63.6(14)$ & $11.1(2)$ & \\
\hline Normal & $20.0(1)$ & $0.0(0)$ & $0.0(0)$ & \\
\hline \multirow{3}{*}{\multicolumn{5}{|c|}{$\begin{array}{l}\text { Psychological stress or acute illness last } 3 \text { months / } \\
\text { Stress psicológico ou doença aguda últimos } 3 \text { meses } \\
\text { Neuropsychological problems / }\end{array}$}} \\
\hline & & & & \\
\hline & & & & \\
\hline Severe dementia / Demência grave & $0.0(0)$ & $27.3(6)$ & $66.7(12)$ & \multirow{3}{*}{0.010} \\
\hline Mild dementia / Demência leve & $100.0(5)$ & $68.2(15)$ & $22.2(4)$ & \\
\hline No problems / Sem problemas & $0.0(0)$ & $4.5(1)$ & $11.1(2)$ & \\
\hline \multirow{2}{*}{\multicolumn{5}{|c|}{$\begin{array}{l}\text { Presence of skin lesions or bedsores / } \\
\text { Presença de lesões na pele ou escaras } \\
\text { Number of meals daily / }\end{array}$}} \\
\hline & & & & \\
\hline \multicolumn{5}{|l|}{ Número de refeições diárias } \\
\hline 1 & $0.0(0)$ & $0.0(0)$ & $5.6(1)$ & \multirow{3}{*}{0.535} \\
\hline 2 & $0.0(0)$ & $0.0(0)$ & $5.6(1)$ & \\
\hline 3 & $100.0(5)$ & $100.0(22)$ & $88.9(16)$ & \\
\hline \multicolumn{5}{|l|}{ Intake of / Consumo de: } \\
\hline $\begin{array}{l}\geq 1 \text { daily portion of milk or dairy products / } \\
1 \text { porção diária de leite ou derivados }\end{array}$ & $100.0(5)$ & $90.9(20)$ & $83.3(15)$ & 0.528 \\
\hline $\begin{array}{l}\geq 2 \text { daily servings of fruit or vegetables / } \\
2 \text { porções diárias de fruta ou hortícolas }\end{array}$ & $100.0(5)$ & $95.5(21)$ & $100.0(18)$ & 0.586 \\
\hline $\begin{array}{l}\text { Meat, fish or poultry every day / } \\
\text { Carne, peixe ou aves todos os dias }\end{array}$ & $100.0(5)$ & $90.9(20)$ & $94.4(17)$ & 0.741 \\
\hline $\begin{array}{l}\geq 2 \text { weekly servings of legumes and eggs / } \\
2 \text { porções semanais de leguminosas e ovos }\end{array}$ & $80.0(4)$ & $90.9(20)$ & $94.4(17)$ & 0.603 \\
\hline \multicolumn{5}{|l|}{ Daily cups of liquid consumed / } \\
\hline \multicolumn{5}{|l|}{ Copos diários de líquidos consumidos } \\
\hline$<3$ & $20.0(1)$ & $18.2(4)$ & $50.0(9)$ & \\
\hline $3-5$ & $20.0(1)$ & $18.2(4)$ & $38.9(7)$ & 0.017 \\
\hline
\end{tabular}

Data expressed as a percentage (n). *p-value for comparisons between groups assessed by Pearson $\chi^{2}$. Abbreviations: BMI, Body Mass Index./ Dados expressos como percentagem (n). *Valor P para comparações entre grupos avaliado por Pearson $\chi^{2}$. Abreviaturas: IMC, Índice de Massa Corporal. 
Our study has several strengths, including the use of a validated and published tool for the assessment of nutritional status. However, some limitations should be assumed. This is a case study with a small sample size which limits the significance of the results, and the existence of other potential correlations. In our small sample, we observed a high prevalence of malnutrition, which negatively affects the general health status of elderly populations and particularly within the institutionalized elderly. However, this study reflects the reality within a single institution. It is important to conduct more systematic and frequent studies in other senior residences and to increase the sample size to strengthen the scientific evidence on the prevalence of states of nutritional risk and malnutrition in institutionalized elderly in our country.

\section{Conclusion}

In this senior residence, we found that the malnutrition and malnutrition risk values are high, highlighting the need for nutritional intervention, as these places need specialized technicians in the area in order to promote a good nutritional status, which is so important, particularly in this age group.

\section{Authors Contributions Statement}

BS conceptualization and study design; BS, DP experimental implementation, and data collection; C.F.-P. data analysis; DP, C.F.-P. drafting, editing, and reviewing; C.F.-P. tables, figures, and graphics; C.F.-P., BS supervision; C.F.-P., BS final writing. noutros trabalhos $(23,24)$. Por outro lado, a presença de lesões na pele ou escaras apenas se observou em idosos desnutridos. Neste sentido, estudos já previamente publicados indicam a existência de associações entre a desnutrição e o desenvolvimento de lesões por pressão e consequentemente a dificuldade da sua cicatrização (21).

O nosso estudo tem vários pontos fortes, como por exemplo a utilização de uma ferramenta validada e publicada para a avaliação do estado nutricional. Contudo, algumas limitações devem ser assumidas. Trata-se de um estudo de caso com uma amostra reduzida o que limita o significado dos resultados, e a existência de outras potenciais correlações. Na nossa pequena amostra, observámos uma elevada prevalência de subnutrição, que afecta negativamente o estado geral de saúde das populações idosas e particularmente no seio dos idosos institucionalizados. Contudo, este estudo reflete apenas a realidade de uma única instituição. É importante realizar de forma mais frequente mais estudos em outras residências sénior, e com uma amostra superior de modo a fortalecer a evidência científica sobre a prevalência, mas sobretudo também a incidência, de risco nutricional e de desnutrição em idosos institucionalizados no nosso país.

\section{Conclusões}

Nesta residência sénior verificamos que os valores de desnutrição e de risco de desnutrição são elevados, evidenciando a necessidade da intervenção nutricional, pois estes locais necessitam de técnicos especializados na área, no sentido de promoverem um bom estado nutricional, tão importante, particularmente nesta faixa etária.

\section{Declaração sobre as contribuições do autor}

B.S. concetualização e conceção do estudo; B.S, D.P. implementação experimental e recolha de dados; C.F.-P. análise de dados; D.P, C.F.- P. redação, edição e revisão; C.F.-P. tabelas, figuras e gráficos; C.F.-P., B.S. supervisão; C.F.-P., B.S. redação final. 


\section{Funding}

Cíntia Ferreira Pêgo is funded by Foundation for Science and Technology (FCT) Scientific Employment Stimulus contract with the reference number CEEC/ $\mathrm{CBIOS} / \mathrm{NUT} / 2018$. This work is funded by national funds through FCT - Foundation for Science and Technology, IP, under the UIDB/04567/2020 and UIDP/ 04567/2020 projects, and ALIES-COFAC PADDICC2021.

\section{Acknowledgments}

The authors acknowledge all the participants.

\section{Conflict of Interests}

All authors have stated that there are no financial and/or personal relationships that could represent a potential conflict of interest.

\section{Financiamento}

Cíntia Ferreira Pêgo é financiada pela Fundação para a Ciência e Tecnologia (FCT) Contrato de Estímulo ao Emprego Científico com o número de referência CEEC/CBIOS/NUT/2018. Este trabalho é financiado por fundos nacionais através da FCT - Fundação para a Ciência e Tecnologia, I.P., ao abrigo dos projetos UIDB/04567/2020 e UIDP/ 04567/2020, e ALIESCOFAC - PADDICC2021.

\section{Agradecimentos}

Os autores agradecem a todos os participantes.

\section{Conflito de Interesses}

Todos os autores declararam que não existem relações financeiras e/ou pessoais que possam representar um potencial conflito de interesses. 


\section{References / Referências}

1. PORDATA - Base de Dados Portugal Contemporâneo. (2015). População residente: total e por grandes grupos etários em Portugal. PORDATA.

2. Ahmed, T., \& Haboubi, N. (2010). Assessment and management of nutrition in older people and its importance to health. Clinical interventions in aging, 5, 207-216. https://doi.org/10.2147/cia.s9664.

3. World Health Organization. (2015). World Report on Aging and Health. Geneve.

4. Serván, P.R., Poyatos, R.S., Rodríguez, J.S., Gómez-Candela, C., Luna, P.P.G., Serra-Majem, L. (2015). Consideraciones y recomendaciones en el caso de estudios nutricionales realizados en adultos mayores. Revista Española de Nutrición Comunitaria 21 (Supl. 1), 81-87. DOI: 10.14642/RENC.2015.21.sup1.5055

5. Bernstein, M., \& Munoz, N. (2012). Position of the Academy of Nutrition and Dietetics: Food and Nutrition for Older Adults: Promoting Health and Wellness. Journal of the Academy of Nutrition and Dietetics, 112(8), 1255-1277.

6. Madeira, T., Peixoto-Plácido, C., Sousa-Santos, N., Santos, O., Alarcão, V., Goulão, B., Mendonça, N., Nicola, P. J., Yngve, A., Bye, A., Bergland, A., Amaral, T. F., Lopes, C., \& Gorjão Clara, J. (2018). Malnutrition among older adults living in Portuguese nursing homes: the PEN-3S study. Public Health Nutrition, 22(3), 486-497. doi:10.1017/S1368980018002318

7. Direção-Geral da Saúde. 2019. Rastreio Nutricional - Documento de apoio à implementação da avaliação do risco nutricional. Lisboa: Direção-Geral da Saúde.

8. Matos, L., Teixeira, M.A., Henriques, A., Tavares, M.M., Alvares, L., Antunes, A., et al. 2007. Nutritional status recording in hospitalized patient notes. Acta Médica Portuguesa, 20(6):503-510.

9. Vellas, B., Villars, H., Abellan, G., Soto, M. E., Rolland, Y., Guigoz, Y., Morley, J. E., Chumlea, W., Salva, A., Rubenstein, L. Z., \& Garry, P. (2006). Overview of the MNA ${ }^{\circledR}$ - Its History and Challenges. The journal of nutrition, health \& aging, 10, 456-465.

10. Rubenstein, L.Z., Harker, J.O., Salva, A., Guigoz, Y., Vellas, B. (2001). Screening for Undernutrition in Geriatric Practice: Developing the Short-Form Mini Nutritional Assessment (MNA-SF). The journals of gerontology. Series A, Biological sciences and medical sciences, 56A, M366-377.

11. Guigoz, Y. (2006) The Mini-Nutritional Assessment (MNA®) Review of the Literature - What does it tell us? The journal of nutrition, health \& aging, 10, 466-487.

12. Chumlea, W.C., Roche, A.F., Steinbaugh, M.L. (1985). Estimating Stature from Knee Height for Persons 60 to 90 Years of Age. Journal of the American Geriatrics Society, 33(2),116-120.

13. Stewart, A., Marfell-Jones, M., Olds, T., De Ridder, H. (2011). ISAK: International Society for Advancement of Kinanthropometry. International standards for anthropometric assessment.

14. Chumlea, W.C., \& Guo, S. (1992). Equations for predicting stature in White and Black elderly individuals. Journal of gerontology, 47(6), M197-203. http://doi.org/10.1093/geronj/47.6.m197

15. Lage, J., Simões, C.D., Combadão, J., Silva, A.P., Valente, A. (2018). Avaliação do risco nutricional em idosos utentes de um centro de saúde de Lisboa. Acta Portuguesa de Nutricao, 14,6-9.

16. Bernardo, S. C. (2013). Estado Nutricional dos Idosos que Frequentam os Centros de Dia e Centros de Convívio do Concelho de Paços de Ferreira (Tese de mestrado, Faculdade de de Ciências da Nutrição e Alimentação da Universidade do Porto). Repositório aberto da Universidade do Porto. https://repositorio-aberto.up.pt/bitstream/10216/66544/4/23883.2.pdf

17. Cereda, T., Pedrolli, C., Klersy, C., Bonardi, C., Quarleri, L., Cappello, S., Turri, A., Rondanelli, M., Caccialanza, R. (2016). Nutritional status in older persons according to healthcare setting: A systematic review and meta-analysis of prevalence data using MNA ${ }^{\circ}$. Clinical nutrition (Edinburgh, Scotland), 35(6),1282-1290. http://doi.org/10.1016/j.clnu.2016.03.008

18. Damo, C.C., Doring, M., Alves, A.L.S., Portella, M.R. (2018). Risk of malnutrition and associated factors in institutionalized elderly persons. Revista Brasileira de Geriatria e Gerontologia 21(6), 711-717. https://doi.org/10.1590/1981-22562018021.180152

19. Saka, B., Ozkaya, H., Karisik, E., Akin, S., Akpinar, T.S., Tufan, F., Bahat, G., Dogan, H., Horasan, Z., Cesur, K., Erten, N., Karan, M.A.(2016). Malnutrition and sarcopenia are associated with increased mortality rate in nursing home residents: A prospective study. European Geriatric Medicine 7(3), 232-238. https://doi.org/10.1016/j.eurger.2015.12.010

20. Serrano-Urrea, R., \& García-Meseguer, M.J. (2014). Relationships between nutritional screening and functional impairment in institutionalized Spanish older people. Maturitas, 78(4), 323-328. https://doi.org/10.1016/j.maturitas.2014.05.021

21. Alfieri, F. M., Silva, N. O. V. E, Kutz, N. A., \& Oliveira, M. M. H. de A. de. (2016, abril-junho). Relações entre equilíbrio, força muscular, mobilidade funcional, medo de cair e estado nutricional de idosos da comunidade. Revista Kairós Gerontologia 19(2), 147-165.

22. Loução, A.T. (2013). Avaliação Nutricional no Idoso (Tese de mestrado, Faculdade de Medicina da Universidade de Coimbra). Repositório Científico da Universidade de Coimbra. http://hdl.handle.net/10316/47650

23. Dos Santos, T.B.N., Fonseca, L.C., Tedrus, G.M.A.S., Delbue, J.L. (2018). Alzheimer's disease: nutritional status and cognitive aspects associated with disease severity. Nutricion hospitalaria, 35(6),1298-1304. http://doi.org/10.20960/nh.2067.

24. Vicente de Sousa, O., Mendes, J., Amaral, T.F. (2020). Nutritional and Functional Indicators and Their Association With Mortality Among Older Adults With Alzheimer's Disease. American journal of Alzheimer's disease and other dementias, 35, 1533317520907168. http:// doi.org/10.1177/1533317520907168. 